\title{
An Assessment of the Role of Water Hyacinth in the Water Level Changes of Lake Naivasha Using GIS and Remote Sensing
}

\author{
Peter Odoyo Agutu*, Moses Karoki Gachari, Charles Ndegwa Mundia \\ Institute of Geomatics, GIS and Remote Sensing, Dedan Kimathi University of Technology, Nyeri, Kenya \\ Email address: \\ ptragutu@gmail.com (P. O. Agutu), gacharimk@yahoo.com (M. K. Gachari),ndegwa.mundia@gmail.com (C. N. Mundia) \\ ${ }^{*}$ Corresponding author
}

To cite this article:

Peter Odoyo Agutu, Moses Karoki Gachari, Charles Ndegwa Mundia. An Assessment of the Role of Water Hyacinth in the Water Level Changes of Lake Naivasha Using GIS and Remote Sensing. American Journal of Remote Sensing. Vol. 6, No. 2, 2018 , pp. 74-88.

doi: 10.11648/j.ajrs.20180602.13

Received: August 14, 2018; Accepted: October 19, 2018; Published: November 19, 2018

\begin{abstract}
Lake Naivasha is an important water resource for Kenya being a fresh-water lake in a region dominated by saltywater lakes. The lake supports several human activities around it. Its water level, though fluctuates, was gradually declining before 2010. The water level rose from March 2010 and has since remained relatively high. As a result, areas around the lake that were previously land surface are currently submerged in water. This is threatening the survival of human activities around the lake. Consequently, the study sought to establish the causes of the lake's water level fluctuations in the period 2000-2016, focusing on the role of rainfall, temperature, human activities around the lake, and water hyacinth. Surface area of the lake covered by water and surface area of the lake covered by water hyacinth were extracted from Landsat images. The SEBAL model was used to estimate evaporation potential over the lake and differences in evaporation over areas covered by water hyacinth and open water surfaces were analysed. Water hyacinth cover was found to have significant, positive correlation with monthly average water levels $(\mathrm{p}<.05)$. Open water surfaces lost significantly higher water volume through evaporation than areas covered by water hyacinth $(\mathrm{p}<.05)$. This suggests that water hyacinth contributes to the high water levels. Rainfall received over Nyandarua slopes, which is the catchment region for in-flow rivers was also an almost statistically significant contributor to lake's water level changes, while temperature was not. On the other hand, growing human activities around the lake seemed to contribute to water level decline through increasing abstraction from the lake. The study recommends more research on, and implementation of better and more ecologically efficient measures for controlling water hyacinth growth in Lake Naivasha.
\end{abstract}

Keywords: Lake Naivasha, Remote Sensing, Water Level, Water Hyacinth, Evaporation, Evapotranspiration

\section{Introduction}

Lake Naivasha plays a very important role in the Kenyan economy being a fresh-water lake in a semi-arid region in Kenya. It supports the life of hundreds of thousands of people living within its basin. Significant agriculture occurs within the $3,376 \mathrm{~km}^{2}$ catchment area, including commercial floriculture and horticulture industry whose growth has increased significantly over the last two decades [1-2]. The lake also provides home to a wide range of aquatic and terrestrial flora and fauna, including fish, birds, plants, etc. Thus, it also supports thriving fishing and tourism industries.
The underground discharge from the lake recharges the geothermal wells around the lake [3-4].

Being in a semi-arid environment, Lake Naivasha experiences high evaporation; in fact, the evaporation is higher than the precipitation it receives $[1,5]$. This means that changes in vegetative cover around or on it can affect the lake's water level, other factors held constant. However, studies which have investigated the lake's water level fluctuations have mainly focused on the role of climate change on the water level [3-4, 6-8]. For example, using parameters such as the hydrological cycle, temperature and precipitation, Arlan predicted that climate change would 
cause the lake water level to decline by $4 \mathrm{~m}$ by 2039 [6]. However, in their study on the changes in water balance trends of the lake for the period 1960-2010, Odongo et al. did not find any correlation between changes in precipitation and decline in the lake volume [7]. This suggests that climate change played a minor role, if any, on the lake's decline over the 50 years examined. The observation made in [7] suggests that there could be other factors responsible for changes in the lake's water level.

The average fluctuation of the water level stands at $1.5 \mathrm{~m}$ yet it has maximum depth of just $11.5 \mathrm{~m}$ [11]. Before 2010, there was a growing concern about Lake Naivasha's water level fluctuations which was largely on a declining trend [5, 6-7, 9-11]. The lake reached its highest peak in 1917 and since then the level has been decreasing gradually, reaching its most recent, lowest level in 2009. Odongo et al. found significant decline in the lake's volume between 1960 and 2010 [7]. The rate of decline was estimated to be $9.35 \times 10^{6}$ $\mathrm{m}^{3}$ per year. This shows that despite the fluctuations, the lake's water level has largely been decreasing.

The declining water level trend ended at the beginning of 2010 and started to rise in wet season of the same year. The trend continued over the next 3 years and was largely attributed to increased rainfall in the lake basin especially around the slopes of Nyandarua which is the sources of the rivers flowing into the lake. However data retrieved from the Kenya Meteorological Department shows that high rainfall was received only in 2010-2011. Even though the high rainfalls have since subsided, the water level remains higher than the previous levels. Areas that were previously land surfaces are today submerged in water. This phenomenon is threatening human activities around the lake, including: residential houses and commercial activities established in the lower parts of Naivasha town near the lake; horticulture and floriculture farms around the lake; hotels around the lake; and geothermal projects around the lake. Parts of hotel compounds built around the lake are today covered by water and the water has moved closer to Naivasha town. The higher water level has been accompanied by large water hyacinth cover over the lake. The most affected parts of the lake are South and North where the weed has covered the entire beaches [13].

While there are a few scholars like Dr. David Harper of University of Leicester who believe that water hyacinth is responsible for the present high lake water level [14], other authors suggest that water hyacinth contributes to the lake water level decline [15]. As in reference $[16,17]$ argued that invasive alien plants, such as the water hyacinth, increase above-ground biomass and evapotranspiration, which suggests that the growth of water hyacinth is likely to reduce the lake's water level. However, the authors' argument is based on invasive alien plants found on land. Meanwhile, studies which have investigated the hydrology of Lake Naivasha or the effects of water hyacinth on the lake and its environs have failed to examine the possibility of the lake drying up under stress caused by the weed or whether the water hyacinth could help reduce evaporation from the lake.
Time series remote-sensing images have been used to map lake size changes [7, 18], estimate evapotranspiration from the lake [19-22], estimate the relationship between lake size changes and horticultural and floricultural activities and climate change [18], estimate lake water volume [23]. This means that geospatial information technology (GIS) and remote sensing can be used to visualise and analyse changes of a lake's water level; establish the role of the water hyacinth cover, precipitation, and temperature on a lake's water level; etc. Availability of remote-sensing images makes it possible to study changes over time in lake size and water hyacinth cover as well as the relationship between lake size changes, water hyacinth cover, and climate change factors such as rainfall and temperature. This study sought to map water hyacinth over Lake Naivasha, and establish the relationship between Lake Naivasha water level changes and rainfall, temperature, human activities, and water hyacinth over the lake, making use of remote sensing (Landsat) images and GIS technology. The goal was to map water hyacinth over Lake Naivasha and determine the role of the weed on the changing water level while taking into consideration the role of rainfall and temperature.

\section{Methodology}

\subsection{Area of Study}

Lake Naivasha is found at $0^{0} 45^{\prime} \mathrm{S}, 36^{\circ} 26^{\prime} \mathrm{E}$, at an altitude of $1885 \mathrm{~m}$. It lies at the floor of the Eastern Rift Valley, covering an area of about $140 \mathrm{~km}^{2}$. The lake's basin is bordered by the Aberdare Mountains to the east, the Mau Escarpment to the west, Mount Longonot to the south, and the Eburru Hills to the north. Among the eight lakes within the Kenyan Rift Valley, it is the only fresh water lake. It has an underground outlet that enables it to maintain freshness. The other lakes within the Kenyan Eastern Rift Valley are Lake Turkana, Baringo, Bogoria, Nakuru, Elementaita, Naivasha, Magadi, and Amboseli.

\subsection{Data and Materials}

This study made use of several types of data, including base maps in shapefile format, meteorological data, water level data, and Landsat satellite images. For each of the variables, the data collected covered the period 2000-2016. Landsat 7 Enhanced Thematic Mapper Plus (ETM+) and Landsat 8 Operational Land Imager (OLI) level 1 images were obtained from the USGS website. The study period covered was from 2000 through to 2016. For each year, at least a single month was retrieved from the database. Image selection was based on lowest cloud cover each year. Geometric corrections were done during data collection such that all the images were aligned to the world geodetic system 1984 (WGS 84) datum and projected to the Universal Transverse Mercator (UTM) zone 36. A total of 32 images were obtained from the database. Table 1 below provides a summary of the data that was collected for the purpose of this study. 


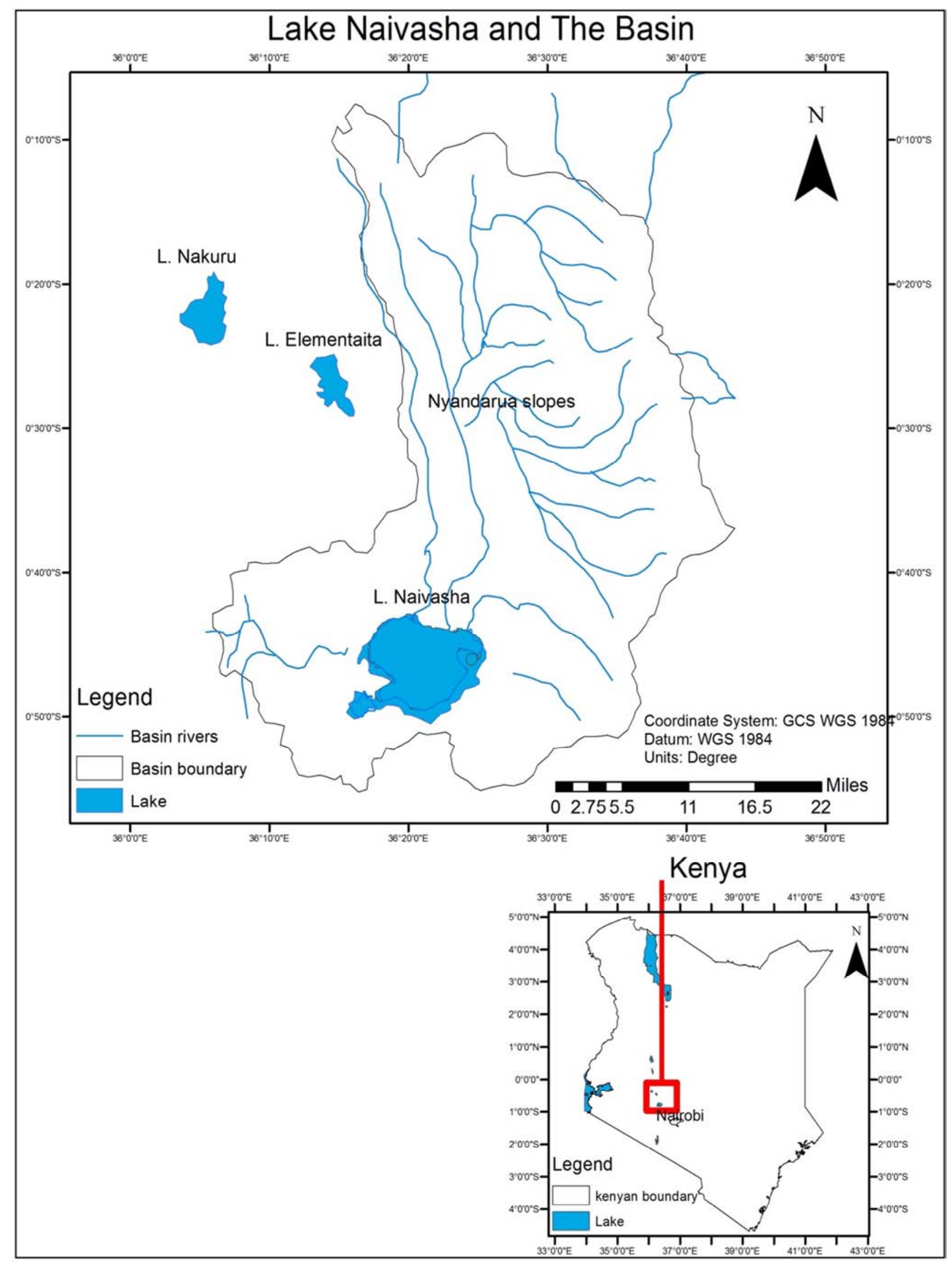

Figure 1. Map of Lake Naivasha Basin. 
Table 1. Summary of the data collected.

\begin{tabular}{llll}
\hline Parameter & Measurement & Period & Source \\
\hline Level 1 Landsat images & $\mathrm{ETM}+$ and OLI & $2000-2016$ & USGS \\
Water level & $\mathrm{m}$ & $2000-2016$ & WARMA \\
Rainfall & $\mathrm{mm}$ & $2000-2016$ & Meteorological Department and NASA \\
Temperature & ${ }^{\circ} \mathrm{C}$ & $2000-2016$ & Meteorological Department \\
Relative humidity & $\%$ & $2000-2016$ & Meteorological Department \\
Wind speed & $\mathrm{Km} / \mathrm{h}$ & $2000-2016$ & Meteorological Department \\
Water vapour & $\mathrm{g} / \mathrm{m}^{3}$ & $2000-2016$ & NASA \\
Basin boundary map & Shapefile & & International Livestock Research Institute (ILRI) \\
Rivers map & Shapefile & & ILRI \\
Lake Naivasha map & Shapefile & WARMA \\
\hline
\end{tabular}

\subsection{Research Design}

The research design developed for this research is summarised in figure 2 below.

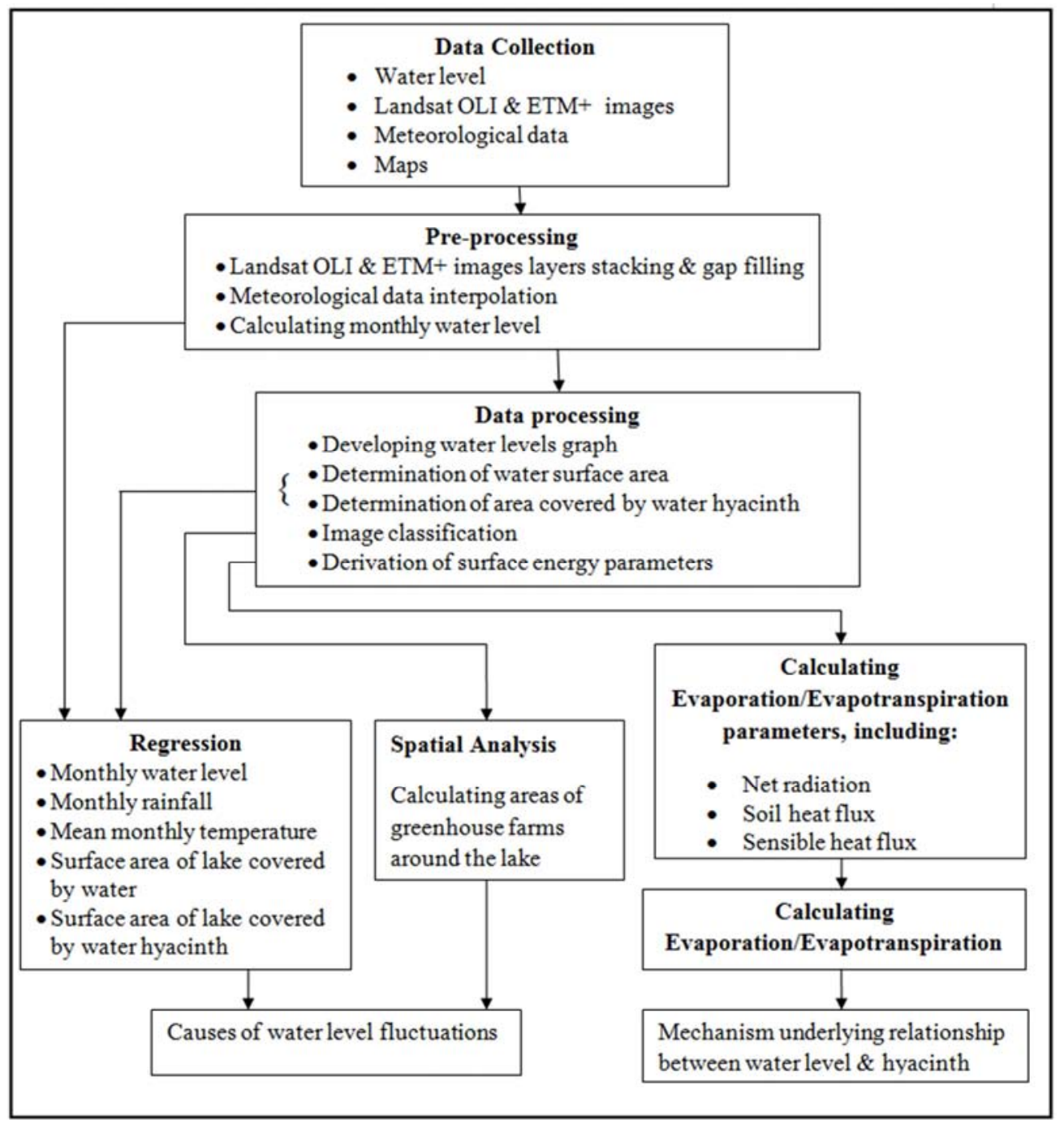

Figure 2. Summary of the research design.

\subsubsection{Data Pre-Processing}

Meteorological data and Landsat images were preprocessed. All the meteorological data were interpolated using ArcGIS (ArcMap 10.1) software to estimate values across every point over the lake and the basin. This was followed by layer stacking of Landsat image bands using
ERDAS Imagine 10 software. For Landsat 7 ETM+ images, band 1 , band 2 , band 3 , band 4 , band 5 , and band 7 were layers stack. Gap filling was done to all ETM+ images captured after 2003 July (Scan Line Corrector (SLC-off)). For Landsat 8 OLI images, band 1, band 2, band 3, band 4, band 5 , band 7 , and band 8 were layers stack. 


\subsubsection{Data processing}

(I) Change detection of area around the lake

Detection of changes around the lake was done through unsupervised classification of the area around the lake, followed by reclassification. Classified images for 2000, 2005, 2010, and 2015 were used to establish changes in floriculture and horticulture around the lake by calculating the areas of greenhouse farms around the lake.

(II) Extraction of area covered by water hyacinth

The lake area was extracted from each image using the lake boundary map (shapefile). Water hyacinth cover delineation was done using the Normalized Difference Vegetation Index (NDVI), by applying the formula:

$$
N D V I=\frac{\mathrm{NIR}-\mathrm{RED}}{\mathrm{NIR}+\mathrm{RED}}
$$

For OLI images, RED = band 4 and near infrared $(\mathrm{NIR})=$ band 5; and for ETM+ images RED = band 3 and near infrared $($ NIR) $=$ band 4 . Surface area covered by water hyacinth $\left(\mathrm{km}^{2}\right)$ was calculated using ArcGIS geostatistical tools.

(III) Extraction of surface area of lake covered by water

Lake water surface was determined by calculating Normalized Difference Water Index (NDWI), using the formula:

$$
N D W I=\frac{\text { GREEN }- \text { SWIR }}{\text { GREEN }+ \text { SWIR }}
$$

For OLI images, GREEN = band 3 and Shortwave infrared $(\mathrm{SWIR})=$ band 6 ; and for ETM + images GREEN $=$ band 2 and Short-wave Infrared (SWIR) $=$ band 5. Surface area of lake covered by water $\left(\mathrm{km}^{2}\right)$ was calculated using ArcGIS geostatistical tools. Area covered by water hyacinth was added to the area covered by water.

(IV) Extraction of surface energy parameters

Estimating at satellite temperature from Landsat images. For ETM+ images, the first step was conversion of thermal bands' (band 61 and band 62) digital numbers into spectral radiance using the algorithm presented below.

$$
L \lambda=\frac{\operatorname{LMax} \lambda-\operatorname{LMin} \lambda}{\text { QCalMax }- \text { QCalMin }} \times(\mathrm{QCal}-\mathrm{QCalMin})+\operatorname{LMin} \lambda
$$

where:

$\mathrm{L} \lambda=$ Spectral Radiance at the sensor's aperture in watts $/\left(\mathrm{m}^{2} *\right.$ ster $\left.* \mu \mathrm{m}\right)$

$\mathrm{QCal}=$ the quantized calibrated pixel value in $\mathrm{DN}$

$\operatorname{LMin} \lambda=$ the spectral radiance that is scaled to QCALMIN in watts $/\left(\mathrm{m}^{2} *\right.$ ster $\left.* \mu \mathrm{m}\right)$

LMax $\lambda=$ the spectral radiance that is scaled to QCALMAX in watts $/\left(\mathrm{m}^{2} *\right.$ ster $\left.* \mu \mathrm{m}\right)$

QCalMin $=$ the minimum quantized calibrated pixel value (corresponding to LMin $\lambda$ ) in $\mathrm{DN}=1$ for LPGS products and NLAPS products processed after $4 / 4 / 2004$; and $\mathrm{DN}=0$ for NLAPS products processed before 4/5/2004

QCalMax = the maximum quantized calibrated pixel value (corresponding to $\mathrm{LMAX} \lambda$ ) in $\mathrm{DN}=255$

The spectral radiances were then converted to at-satellite temperature using the formula:

$$
T=\frac{\mathrm{K} 2}{\ln \left(\frac{\mathrm{K} 1}{\mathrm{~L} \lambda}\right)+1}
$$

where:

$\mathrm{T}=$ Effective at-satellite temperature in Kelvin

$\mathrm{K} 2=$ Calibration constant

$\mathrm{K} 1=$ Calibration constant

$\mathrm{L} \lambda=$ Spectral radiance in watts $/\left(\mathrm{m}^{2} * \mathrm{sr} * \mu \mathrm{m}\right)$

At-satellite temperature from band 61 and band 61 were averaged to find the at-satellite temperature. For OLI images, at-satellite temperature estimation involved conversion of Thermal Infrared Sensor (TIRS) bands' (band $10 \&$ band 11) digital values into top of atmosphere (TOA) spectral radiance using the rescaling parameters provided in the Landsat metadata file based on the formula:

$$
L_{\lambda}=M_{L} Q C a l+A_{L}
$$

where:

$$
\left.\mathrm{L}_{\lambda}=\text { TOA spectral radiance (Watts } /\left(\mathrm{m}^{2} * \mathrm{sr} * \mu \mathrm{m}\right)\right)
$$

$\mathrm{M}_{\mathrm{L}}=$ Band-specific multiplicative rescaling factor from the metadata (RADIANCE_MULT_BAND_x, where $\mathrm{x}$ is the band number)

$\mathrm{A}_{\mathrm{L}}=$ Band-specific additive rescaling factor from the metadata (RADIANCE_ADD_BAND_x, where $\mathrm{x}$ is the band number)

$\mathrm{Q}_{\mathrm{cal}}=$ Quantized and calibrated standard product pixel values $(\mathrm{DN})$

This was followed by conversion of the TOA spectral radiance into AT-satellite brightness temperature making use of the thermal constants provided in the metadata file, using the equation:

$$
T=\frac{\mathrm{K} 2}{\ln \left(\frac{\mathrm{K} 1}{\mathrm{~L} \lambda}\right)+1}
$$

where:

$\mathrm{T}=$ At-satellite brightness temperature $(\mathrm{K})$

$\mathrm{L}_{\lambda}=$ TOA spectral radiance (Watts $/\left(\mathrm{m}^{2} * \mathrm{sr} * \mu \mathrm{m}\right)$ )

$\mathrm{K}_{1}=$ Band-specific thermal conversion constant from the metadata (K1_CONSTANT_BAND_x, where $\mathrm{x}$ is the thermal band number)

$\mathrm{K}_{2}=$ Band-specific thermal conversion constant from the metadata (K2_CONSTANT_BAND_x, where $\mathrm{x}$ is the thermal band number)

At-satellite temperature (air temperature) was determined by calculating average of at-satellite temperature from band 10 and band 11 .

Estimating ground surface temperature. For ETM+ images, this involved calculating several surface energy parameters including surface emissivity, atmospheric transmittance from water vapour, and the effective mean atmospheric temperature. Calculation of surface emissivity involved estimating the proportion of vegetation $(\mathrm{Pv})$ as follows:

$$
P v=\left(\frac{\text { NDVI - NDVImin }}{\text { NDVImax - NDVImin }}\right)^{2}
$$


Using Widyasamratri et al.'s equation, we calculated surface emissivity as follows [24]:

$$
\mathrm{e}=0.004 \mathrm{Pv}+0.986
$$

Atmospheric transmittance $\left(\tau_{6}\right)$ was derived from water vapour content using the following equations:

$$
\begin{gathered}
\tau_{6}=0.974290-0.08007 \omega, \text { where water vapour }(\omega)=0.4- \\
1.6 \mathrm{~g} \mathrm{~cm}^{-2} \\
\tau_{6}=1.031412-0.11536 \omega, \text { where water vapour }(\omega)=1.6- \\
3.0 \mathrm{~g} \mathrm{~cm}^{-2}
\end{gathered}
$$

The effective mean atmospheric temperature (Ta) was derived using simple linear equation based on To (near surface air temperature) as follows:

$$
\mathrm{Ta}=17.9769+0.91715 \mathrm{To} \text { for the tropical region }
$$

Ground surface temperature was derived from Landsat ETM+ band 61 using [25] mono-window algorithm:

$$
T s=\frac{\mathrm{a} 6(1-\mathrm{C} 6-\mathrm{D} 6)+(\mathrm{b} 6(1-\mathrm{C} 6-\mathrm{D} 6)+\mathrm{C} 6+\mathrm{D} 6) \text { Tsensor }-\mathrm{D} 6 \mathrm{Ta}}{\mathrm{C} 6}
$$

where:

Ts $=$ the land surface temperature $(\mathrm{K})$,

Tsensor $=$ the brightness temperature $(\mathrm{K})$ derived from Landsat ETM+ band6,

$\mathrm{Ta}=$ the effective mean atmospheric temperature $(\mathrm{K})$,

$\mathrm{a} 6=$ constants, -67.355351 when the LST is between 273.5 and $343.5 \mathrm{~K}$,

b6 = constants, 0.458606 for b6 when the LST is between 273.5 and $343.5 \mathrm{~K}$.

C6 and D6 were calculated using the following equations:

$$
\begin{gathered}
C 6=\varepsilon 6 \tau 6 \\
D 6=(1-\tau 6)(1+(1-\varepsilon 6) \tau 6
\end{gathered}
$$

where:

$\varepsilon_{6}=$ ground surface emissivity

$\tau_{6}=$ atmospheric transmittance

For Landsat OLI images, ground surface temperature was estimated derived from at-satellite temperature using the formula:

$$
T S=\frac{T b}{\left(1+\lambda \times\left(\frac{T b}{\rho}\right) \times \ln e\right)}
$$

where:

$\mathrm{Tb}=$ At satellite temperature

$\lambda=$ wavelength of emitted radiance $(11.5 \mu \mathrm{m})$

$\rho=\mathrm{h} * \mathrm{c} / \mathrm{s}\left(1.438 * 10^{-2} \mathrm{~m} \mathrm{~K}\right)=0.01438 \mathrm{~m} \mathrm{~K}$

$\mathrm{h}=$ Planck's constant $\left(6.626 * 10^{-34} \mathrm{Js}\right)$

$\mathrm{s}=$ Boltzmann constant $\left(1.38 * 10^{-23} \mathrm{~J} / \mathrm{K}\right)$

$\mathrm{c}=$ velocity of light $\left(2.998 * 10^{8} \mathrm{~m} / \mathrm{s}\right)$

$\mathrm{e}=$ surface emissivity

This was calculated for both band 10 and band 11 and the values averaged to determine the ground surface temperature.

Calculating albedo. Estimating surface albedo involved calculating surface reflectance and using the reflectance values to calculate albedo. For ETM+ images, surface reflectance was estimated using the following algorithm:

$$
\rho_{p}=\frac{\Pi \times \mathrm{L}_{\lambda} \times \mathrm{d}^{2}}{\operatorname{ESUN}_{\lambda} \times \cos \theta_{\mathrm{s}}}
$$

where:

$$
\rho_{\mathrm{p}}=\text { Unitless planetary reflectance }
$$

$\mathrm{L}_{\lambda}=$ Spectral radiance at the sensor's aperture (watt $\mathrm{m}^{-2}$ ster $^{-1} \mu \mathrm{m}^{-1}$ )

$\mathrm{d}=$ Earth-Sun distance in astronomical units ((in astronomical units, where 1.0 = average Earth-Sun distance)

$\mathrm{ESUN}_{\lambda}=$ Mean solar exo-atmospheric irradiances (watt $\mathrm{m}^{-}$ ${ }^{2} \mu \mathrm{m}^{-1}$ )

$\theta=$ Solar zenith angle in degrees

Just like in ETM+ images, spectral radiance for OLI images was converted into top of atmosphere reflectance using the formula:

$$
\rho \lambda^{\prime}=M \rho \times Q C a l+A \rho
$$

where:

$\rho \lambda^{\prime}=$ TOA Planetary Spectral Reflectance, without correction for solar angle (Unitless)

$\mathrm{M} \rho=$ Reflectance multiplicative scaling factor for the band (REFLECTANCE_MULT_BAND)

$\mathrm{A} \rho=$ Reflectance additive scaling factor for the band (REFLECTANCE_ADD_BAND_N from the metadata).

Qcal $=\mathrm{L} 1$ pixel value in $\mathrm{DN}$

Based on the calculated top of atmosphere (TOA) reflectance, Smith's algorithm for calculating Landsat shortwave albedo [26] was used to estimate surface albedo.

$$
\alpha_{\text {short }}=\frac{0.356 \rho 1+0.130 \rho 3+0.373 \rho 4+0.085 \rho 5+0.072 \rho 7-0.0018}{0.356+0.130+0.373+0.085+0.072}
$$

where: $\rho=$ landsat bands $1,3,4,5$, and 7

Incoming short-wave radiation $\left(\mathrm{R}_{\mathrm{s}(\mathrm{in})}\right)$. This is a function of direct and diffuse radiation. It was calculated using [27] formula, which makes use of water vapour pressure at the satellite level. Therefore, we first estimated the water vapour pressure. We began by estimating air pressure using the hypsometric formula:

$$
P=P_{0}\left(1-\frac{0.0065 h}{T+0.0065 h+273.15}\right)^{5.257}
$$

where $\mathrm{P}_{0}=101325$

$\mathrm{h}=$ altitude of the lake

$\mathrm{T}=$ screen level temperature observed from ground measurement instrument

The air pressure obtained through the hypsometric equation was used to estimate saturation water vapour pressure based on [28] formula:

$$
\mathrm{e}_{0}=6.108 \times \exp \left(\frac{17.27 \mathrm{To} o}{237.3+\mathrm{T} o}\right)
$$

where To is the screen level temperature in ${ }^{\circ} \mathrm{C}$ and $\rho$ is in $\mathrm{kPa}$. 
Using the estimated saturation water vapour pressure, we calculated water vapour pressure using the formula for determining relative humidity, which is defined as "the ratio of water vapour pressure to the saturation water vapour pressure over water surface at the gas temperature" [29, p. 3].

$$
P V=\frac{\Phi \text { Psat }}{100}
$$

where:

$\mathrm{Pv}=$ vapour pressure of water

$\Phi=$ relative humidity

Psat $=$ Saturation vapour pressure

After determining the vapour pressure of water, Sun et al.'s equation [27] was used to estimate incoming shortwave radiation as follows:

$$
R_{S(\text { in })}=\frac{\cos \theta}{1.2 \cos \theta+e_{0}(1.0+\cos \theta) \times 10^{-2}+0.0455} \times \frac{S_{0}}{d^{2}} \times \cos \theta
$$

where:

$\mathrm{e}_{0}=$ water vapour pressure at the satellite level;

$\mathrm{S}_{0}=$ solar constant, $1367 \mathrm{~W} / \mathrm{m}^{2}$;

$\theta=$ solar zenith angle, rad;

$\mathrm{d}=$ Earth-sun distance, AU; and

$$
\frac{\cos \theta}{1.2 \cos \theta+e_{0}(1.0+\cos \theta) \times 10^{-2}+0.0455}=\text { transmissivity }(\mathrm{t})
$$

Calculating thermal (sky) emissivity. To calculate thermal emissivity, we first calculated dew point temperature (Tdp) using the formula:

$$
T d p=T-\frac{(100-\mathrm{RH})}{5}
$$

where $\mathrm{T}=$ observed temperature

$\mathrm{RH}=$ relative humidity

We used the Tdp derived above to calculate thermal emissivity using [30] equation for calculating clear sky emissivity.

$$
\varepsilon_{s}=0.711+0.56\left(\frac{T d p}{100}\right)+0.73\left(\frac{T d p}{100}\right)^{2}
$$

where Tdp is dew point temperature in degrees Celsius

Estimating moist air density $\left(\rho_{\mathrm{a}}\right)$. м0ist air density $\left(\mathrm{kg} / \mathrm{m}^{3}\right)$ was estimated using the formula below.

$$
\rho_{a}=\frac{p_{d}}{R_{d} \times T}+\left(\frac{P_{v}}{R_{v} \times T}\right)
$$

where $\mathrm{P}_{\mathrm{d}}=$ Partial pressure of dry air $(\mathrm{Pa})$

$\mathrm{R}_{\mathrm{d}}=$ Specific gas constant for dry air, $287.05 \mathrm{~J} /(\mathrm{kg} . \mathrm{k})$

$\mathrm{T}=$ Temperature $\left({ }^{\circ} \mathrm{K}\right)$

$\mathrm{P}_{\mathrm{V}}=$ Partial pressure of water vapour $(\mathrm{Pa})$

$R_{v}=$ Specific gas constant for water vapour, $461.495 \mathrm{~J} /(\mathrm{kg}$. $\mathrm{k})$

Partial pressure of dry air, $\mathrm{Pa}=\rho(286.9 \mathrm{~J} / \mathrm{kg} \mathrm{k}) \mathrm{T}$

Partial pressure of water vapour, $\mathrm{Pv}=\rho \omega(461.5 \mathrm{~J} /(\mathrm{kg} . \mathrm{k}))$

$\mathrm{T}$,

$\rho$ is absolute air pressure

$\rho \omega$ is density of water $\left(\mathrm{kgm}^{-3}\right)$

Aerodynamic resistance to heat transport $(\mathrm{s} / \mathrm{m})$. This was estimated from [31] equation:

$$
r_{a h}=\ln \left\{\frac{\frac{z-d}{z_{0}}}{k}\right\}^{2} \div U
$$

where:

$\mathrm{z}=$ the reference height above the water surface $(\mathrm{m})$

$\mathrm{d}=$ the zero plane displacement $(\mathrm{m})$

$\mathrm{z}_{0}=$ the roughness length approximated as 0.136 of vegetation height $\left(\mathrm{h}_{0}\right) \mathrm{m}$ and 0.0002 for open water surface [32]

$$
\begin{aligned}
& \mathrm{k}=\text { von Karman constant, } 0.42 \\
& \mathrm{U}=\text { wind speed. }
\end{aligned}
$$

$\mathrm{d}$ was estimated from the mean vegetation height $\mathrm{h}_{0}$ using [33] equation $d=0.667 \mathrm{~h}_{0}$. The mean height of water hyacinth is estimated at $0.5 \mathrm{~m}$ [34]. Since water hyacinth only covers proportion of the lake, $\mathrm{h}_{0}$ was multiplied by the proportion of the lake covered by water hyacinth based on [35] equation for estimating roughness length for heat transfer over partly vegetated surfaces.

\subsubsection{Regression Analysis}

Single and multiple linear regression analysis were employed to analyse the relationship between lake water level and water hyacinth cover, rainfall, rainfall and temperature. Regression model coefficients were used to determine the relationships.

\subsubsection{Calculating Evaporation/Evapotranspiration Parameters}

The SEBAL model was used to calculate evaporation/evapotranspiration. The primary component of the SEBAL model is the surface energy. This is determined by calculating the instantaneous $\mathrm{ET}_{\mathrm{act}}$ flux for each cell of the remote sensing image using the equation [36-37]:

$$
L T=R n-G-H
$$

where;

$\mathrm{LT}=$ the latent heat flux $\left(\mathrm{W} / \mathrm{m}^{2}\right)$

$\mathrm{Rn}=$ the net radiation flux at the surface $\left(\mathrm{W} / \mathrm{m}^{2}\right)$

$\mathrm{G}=$ the soil heat flux $\left(\mathrm{W} / \mathrm{m}^{2}\right)$

$\mathrm{H}=$ the sensible heat flux to the air $\left(\mathrm{W} / \mathrm{m}^{2}\right)$

The estimation of evaporation/evapotranspiration rates makes use of the surface energy parameters estimated through the procedures described above (equation 3-26).

Net radiation $(\mathrm{Rn}) . \mathrm{Rn}$, which is the actual radiant energy available at the surface, is computed by subtracting all outgoing radiant fluxes from all incoming radiant fluxes using the equation below.

$$
R n=R_{S(\mathrm{in})}-\alpha R_{S(\mathrm{in})}+R_{L(\mathrm{in})}-R_{L(\mathrm{out})}-\left(1-\varepsilon_{0}\right) R_{L(\mathrm{in})}
$$

where; $\mathrm{R}_{\mathrm{s}(\mathrm{in})}=$ the incoming short-wave radiation $(\mathrm{W} / \mathrm{m} 2)$, which is radiation emitted from the sun

$a=$ the surface albedo

$\mathrm{R}_{\mathrm{L}(\mathrm{in})}=$ the incoming long wave radiation $(\mathrm{W} / \mathrm{m} 2)$

$\mathrm{R}_{\mathrm{L}(\text { out })}=$ the outgoing long wave radiation $(\mathrm{W} / \mathrm{m} 2)$; and

$\varepsilon_{0}=$ the surface thermal emissivity (dimensionless). 
Incoming longwave radiation is calculated as $\varepsilon_{\mathrm{s}} \sigma \mathrm{Ts}^{4}$, where $T_{\mathrm{s}}$ is the sky temperature and $\varepsilon_{\mathrm{s}}$ is the sky emissivity; and outgoing longwave radiation is calculated as $\varepsilon_{0}$, where $\varepsilon_{0}$ is the surface emissivity and $T_{0}$ is the surface temperature. Therefore, Rn can also be expressed in terms of surface albedo, emissivity as well as temperature [37]. The equation is:

$$
R n=(1-\alpha) R_{s(i n)}+\varepsilon_{\alpha} \sigma T_{\alpha}^{4}-\varepsilon_{s} \sigma T_{s}^{4}
$$

Where: $\sigma=$ the Stefan-Boltzmann constant $\left(5.67 \times 10^{-8}\right.$ $\left.\mathrm{W} /\left(\mathrm{m}^{2} \mathrm{~K}^{4}\right)\right)$;

$\mathrm{T}_{\mathrm{a}}=$ the air temperature $(\mathrm{K})$;

$\mathrm{T}_{\mathrm{S}}=$ the land surface temperature $(\mathrm{K})$; and

$\mathrm{a}=$ the surface albedo

$\varepsilon_{\mathrm{a}}=$ air thermal emissivity

$\varepsilon_{\mathrm{s}}=$ ground surface emissivity

Soil heat flux (G0). In this study, the soil heat flux was calculated using relationship between the net radiation, surface albedo, NDVI, and surface temperature. This was done using [38] equation for SEBAL:

$$
G_{0} / R n=T_{s} \times(0.0038+0.0074 \alpha) \times\left(1-0.98 N D V I^{4}\right)
$$

This implies that:

$$
G_{0}=T_{S} \times(0.0038+0.0074 \alpha) \times\left(1-0.98 N D V I^{4}\right) \times R n
$$

Sensible heat flux $(\mathrm{H})$. Sensible heat flux is the rate of heat loss to the air by convection as well as conduction as a result of temperature difference, calculated as:

$$
H=\frac{\rho_{\alpha} C_{P}\left(T_{o}-T_{\alpha}\right)}{r_{a h}}
$$

where: $\rho_{\mathrm{a}}=$ the moist air density $\left(\mathrm{kg} / \mathrm{m}^{3}\right)$

$\mathrm{C}_{\mathrm{p}}=$ the specific heat capacity of air at constant pressure $(\mathrm{J} /(\mathrm{kg} \mathrm{K})(1.005)$

$\mathrm{Ta}=$ the average air temperature $(\mathrm{K})$ at screen height (typically at $2 \mathrm{~m}$ ),

To $=$ the average surface aerodynamic temperature $(\mathrm{K})$, $\mathrm{r}_{\mathrm{ah}}=$ the aerodynamic resistance to heat transport $(\mathrm{s} / \mathrm{m})$

\subsubsection{Calculating Evaporation/Evapotranspiration Rates}

We began by calculating the latent heat flux (LE), which is the amount of energy $\left(\mathrm{Wm}^{-2}\right)$ required for evaporation/evapotranspiration. It is calculated as the residual of the surface energy balance. This is done by closing the energy budget on a pixel-by-pixel basis latent heat flux using the equation:

$$
L E=R n-H-G_{0}
$$

We then calculated evaporative fraction (EF) based on the $\mathrm{Rn}, \mathrm{G}_{0}$, and $\mathrm{H}$ estimates at the time of satellite overpass. This is calculated at each pixel of the image as:

$$
E F=\frac{R n-H-G_{0}}{R n-G_{0}}
$$

The assumption is that EF calculated for the time of satellite overpass is constant over the 24-hour period for the day the image is acquired. Consequently, daily ET at each pixel in the image was computed as:

$$
E T_{24}=\frac{8.64 \times 10^{7}-E F \times\left(R n_{24}-G_{24}\right)}{\lambda-\rho \omega}
$$

where $\lambda$ is latent heat of evaporization $\left(\mathrm{Jkg}^{-1}\right)$, and $\rho \omega$ is density of water $\left(\mathrm{kgm}^{-3}\right)$ [36].

Finally, independent samples t-test was used to determine the statistical significance of the difference in evaporation/evapotranspiration between the lake areas covered by water hyacinth and open lake areas.

\section{Results}

\subsection{Water Level Fluctuations in Lake Naivasha}

\subsubsection{Lake Water Level}

The water level rose from near zero metres above the reference height in March 2009 to above $4.5 \mathrm{~m}$ in August 2013. It has since remained above $3.0 \mathrm{~m}$ above the reference height for most of the time as shown in figure 3 below.

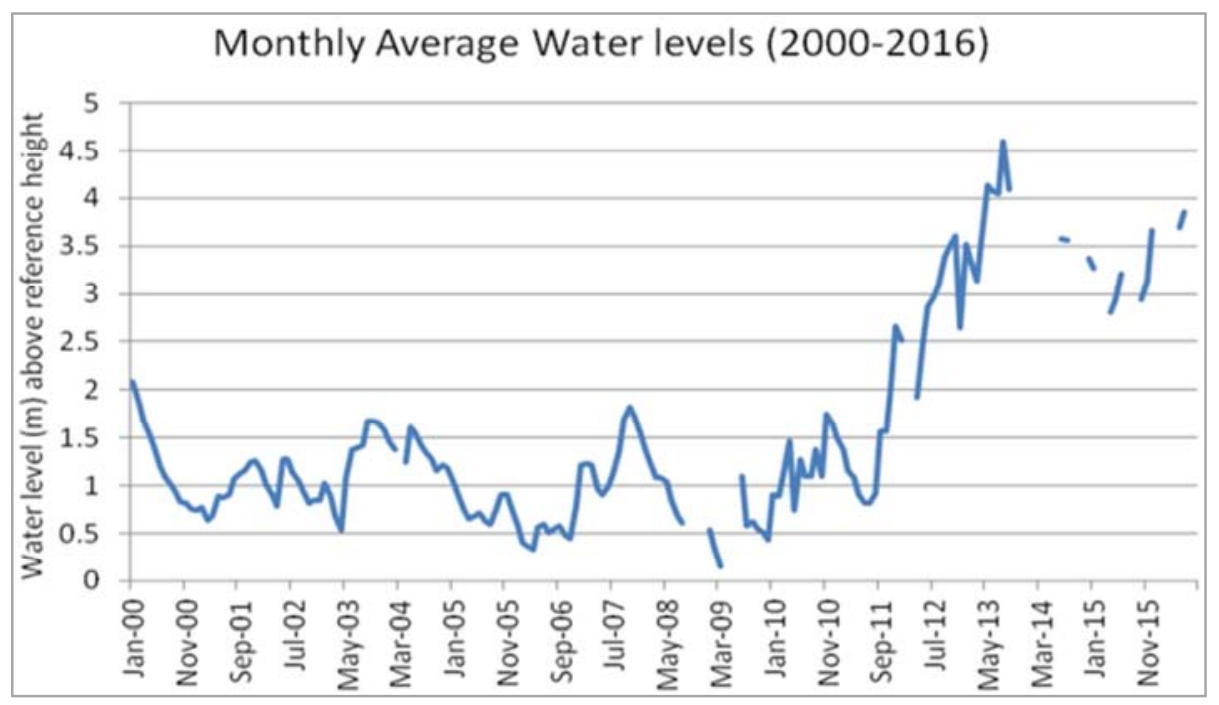

Figure 3. Monthly average water levels over the period 2000-2016. 


\subsubsection{Lake surface area changes}

Further evidence of water level fluctuations is provided by the estimated surface of area of the lake covered by water presented in appendix A1 and figure 4 below.

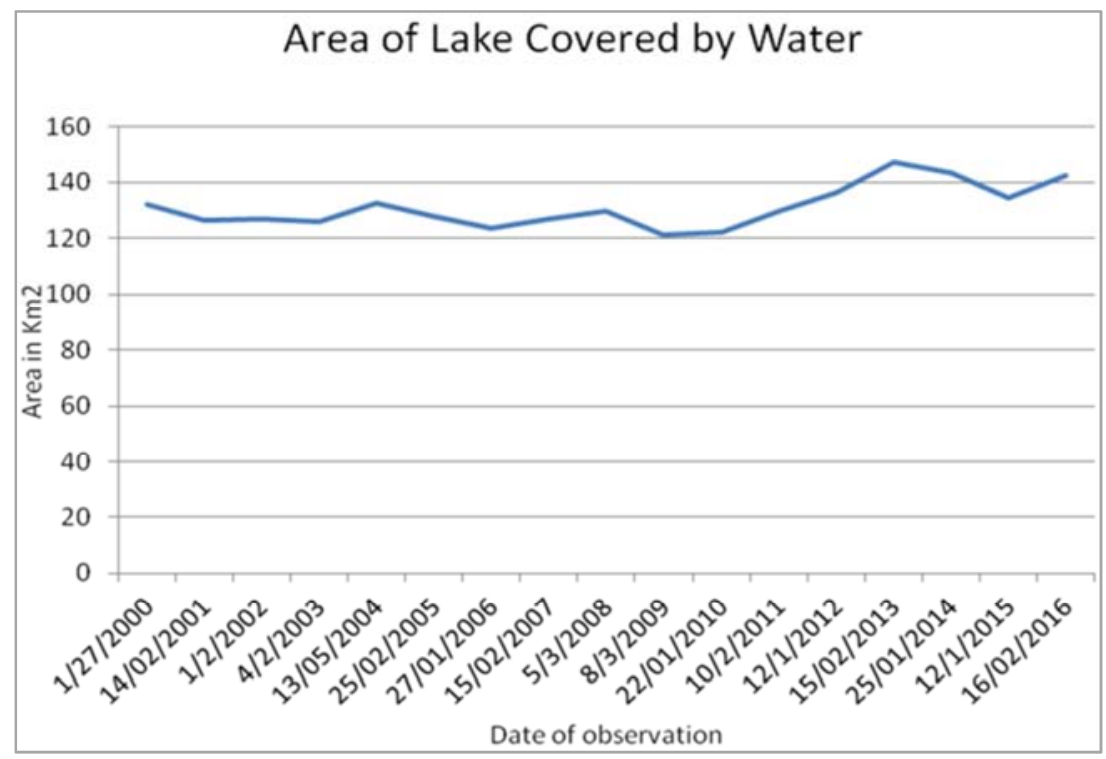

Figure 4. Lake area fluctuations in the period 2000-2016.

Fluctuations in the area covered by water are favourably comparable to the annual water levels as measured and recorded by the Kenya Water Resources Management
Authority. The water level/surface experienced significant increase from 2011 to 2014 and remained relatively high up to 2016, which was the end of the study period.

\subsection{Spatial-temporal Growth of Water Hyacinth over Lake Naivasha}
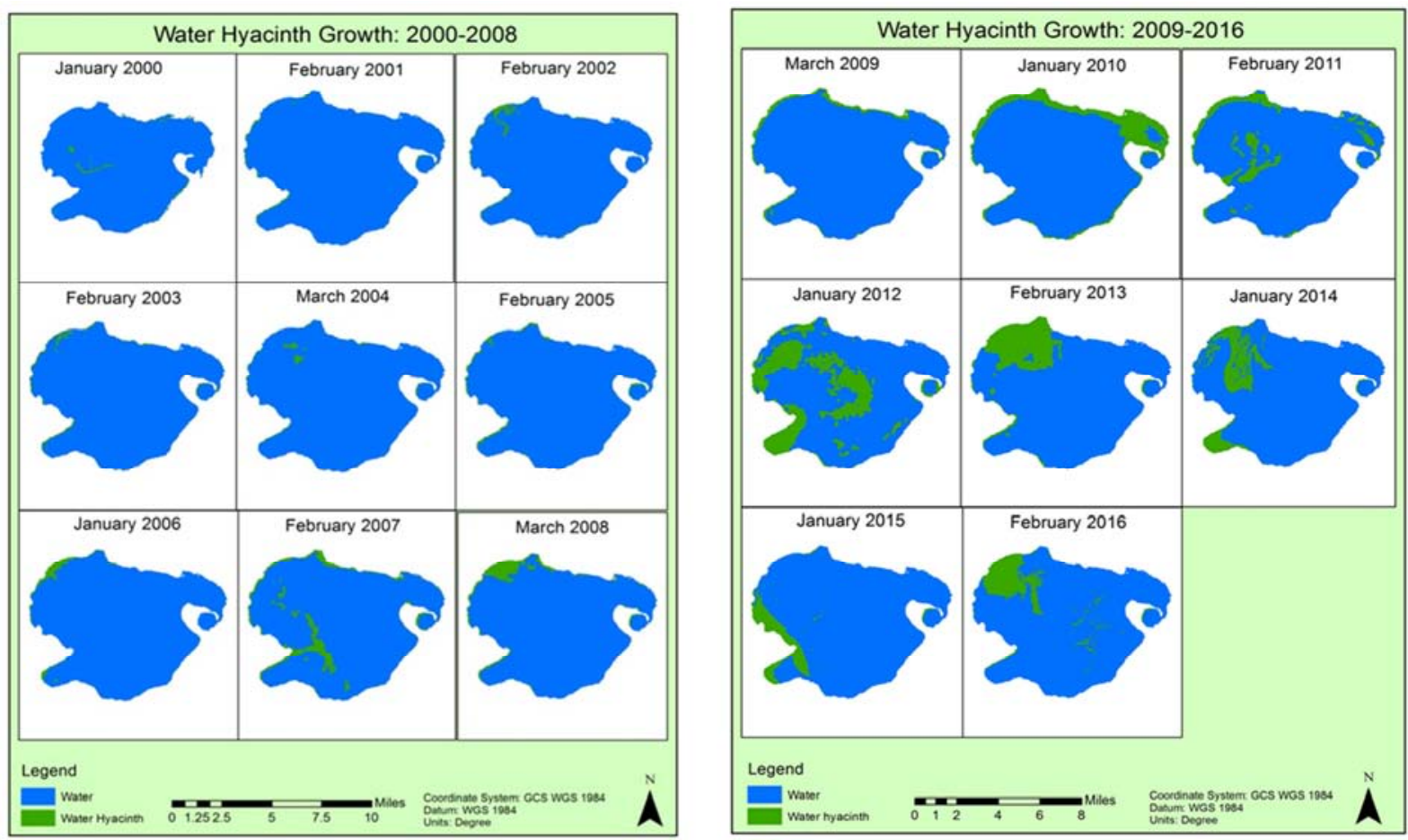

Figure 5. Water hyacinth growth over the lake (2000-2016).

There was particularly high water hyacinth cover in 2012 . The water hyacinth covered an area of about $31 \mathrm{~km}^{2}$ in January 2012, which is far much larger than the situation in
January $2000\left(1.23 \mathrm{~km}^{2}\right)$. The spatial-temporal growth of water hyacinth over $2000-2016$ is presented below. The western part of the lake, from north to south, is particularly 
more affected by the weed. However, water hyacinth cover over the lake has been declining since its peak in 2012-2014. Appendix A2 shows the surface area covered by water hyacinth $\left(\mathrm{km}^{2}\right)$. Water hyacinth over the lake in 2012 was almost a quarter of the lake surface.

\subsection{Results of Regression Analysis}

The study did not find any evidence between monthly rainfall over the lake and water level in the lake or the surface area of the lake covered by water. Likewise, annual temperatures over the lake have remained relatively constant at $16-17^{\circ} \mathrm{C}$ since 2000 . There was no relationship between mean monthly temperature over the lake and water level in the lake or the surface area of the lake covered by water.

Table 2. Model coefficients for estimating average monthly water level.

\begin{tabular}{llll}
\hline Factor & Coefficient & Std. Error & $\mathbf{p}$ \\
\hline Monthly rainfall over lake Naivasha & .007 & .006 & 1.238 \\
Rainfall over catchment region & .008 & .004 & 1.762 \\
Temperature & .207 & .187 & 1.109 \\
Area of lake covered by water hyacinth $\left(\mathrm{km}^{2}\right)$ & .065 & .026 & .089 \\
\hline
\end{tabular}

Table 3. Model coefficients for estimating surface area of lake covered by water.

\begin{tabular}{|c|c|c|c|c|}
\hline Factor & Coefficient & Std. Error & $\mathbf{t}$ & $\mathbf{p}>|\mathbf{t}|$ \\
\hline Rainfall received in the catchment region & .054 & .027 & 1.957 & .059 \\
\hline Temperature & .428 & 1.165 & .367 & .716 \\
\hline Area of lake covered by water hyacinth $\left(\mathrm{km}^{2}\right)$ & .618 & .171 & 3.624 & .001 \\
\hline
\end{tabular}

The p-values for model coefficients in table 2 and table 3 show that area of lake covered by water hyacinth was the only statistically significant predictor of either mean monthly water level or surface area of the lake filled with water. The amount of rainfall in the catchment region for the rivers flowing into the lake seems to be an important determinant though this study did not find an absolute significant relationship between rainfall in this region and water level in the lake. The analysis showed almost significant relationship between rainfall received over Nyandarua slopes and the surface area of the lake covered by water as well as the lake's water level. The relationship between the area of the lake covered by water hyacinth and average monthly water level was insignificant after adjusting for the effect of monthly rainfall received over the catchment region and mean monthly temperature over the lake $(\beta=.051 ; \mathrm{t}=1.741, \mathrm{p}$ $=.095)$. On the other hand, the results relationship between water hyacinth cover over the lake and surface area of the lake covered by water remained statistically significant even

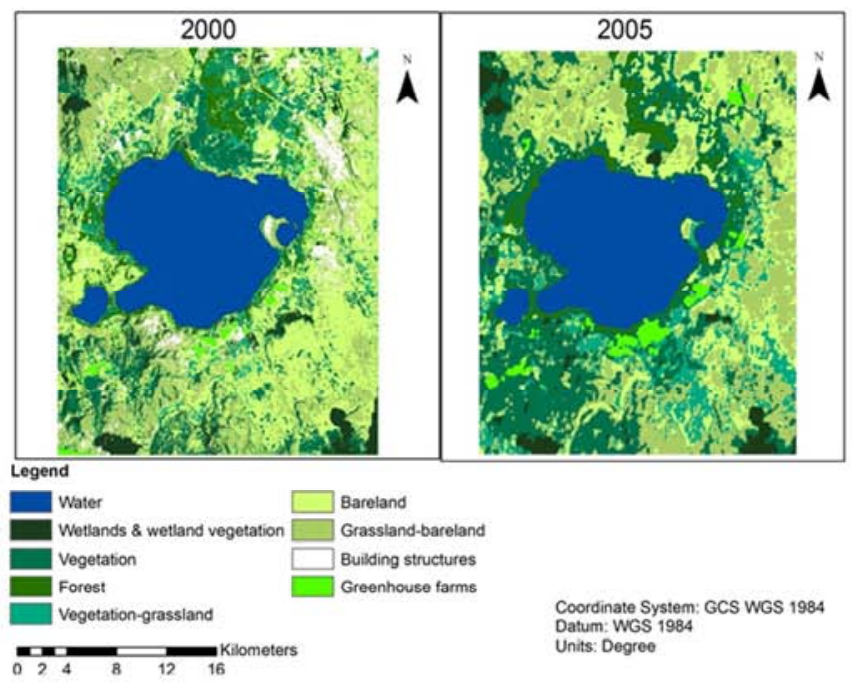

after controlling for the effect of rainfall received around Nyandarua slopes and temperature over the lake $(\beta=.573 ; \mathrm{t}$ $=3.024, \mathrm{p}<.01)$.

\subsection{Human Activities Around the Lake}

Unsupervised classification followed by reclassification was performed to determine the growth in agriculture and human settlements around the lake, comparing the area around the lake as captured in January 2000, February 2005, January 2010, and January 2015. The classified images are presented in the figure 6 below. The change detection showed serious changes in human activities and land cover.

The areas greenhouse (horticulture \& floriculture) farms covered $34.4 \mathrm{~km}^{2}$ in 2000 and $62.3 \mathrm{~km}^{2}$ in 2015. 2005 and 2010 estimates were significantly affected by the scan lines in ETM+ SLC-off images to the extent that they under-represent the actual areas on the ground. The image classification yielded producer's accuracy of $87 \%$ for 2000 image, $84 \%$ for 2005 image, $94 \%$ for 2010 image, $97 \%$ for 2015 image.

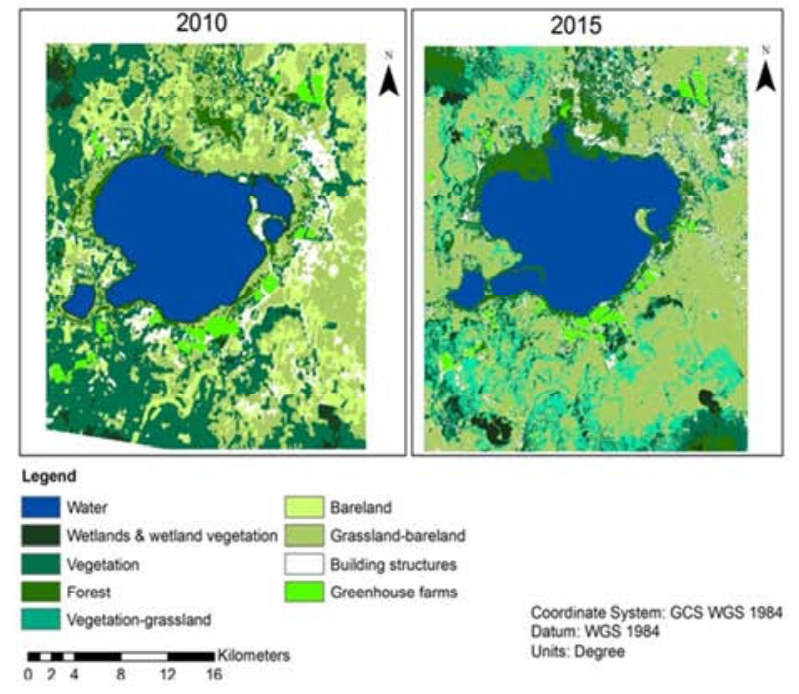

Figure 6. Changes in area where horticulture and floriculture farming occurs. 


\subsection{Effect of Water Hyacinth on \\ Evaporation/Evapotranspiration}

Figure 7 below clearly shows differences in water loss through surface heating between areas covered by water hyacinth and open water surfaces across the lake. The image used to calculate evaporation/evapotranspiration was captured on $12 / 01 / 2012$. As evident in the image, areas covered by water hyacinth had lower water loss than open water surface areas of the lake. Areas covered by water hyacinth fall in the lower 3 classes while open water surfaces are in the top 2 classes.

Evaporation/evapotranspiration rates were also analyzed for eleven other images. The average rates of water loss in open surfaces and water hyacinth covered areas are presented in appendix A3. Paired samples t-test was conducted to determine statistical significance of the observed differences. The paired samples test showed statistically significant difference in water loss through surface heating between open water surfaces and areas covered by water hyacinth, with $\mathrm{t}(11)=7.668, \mathrm{p}<.05$. Evaporation estimates showed that areas covered by water hyacinth experienced significantly lower evaporation than open water surfaces.

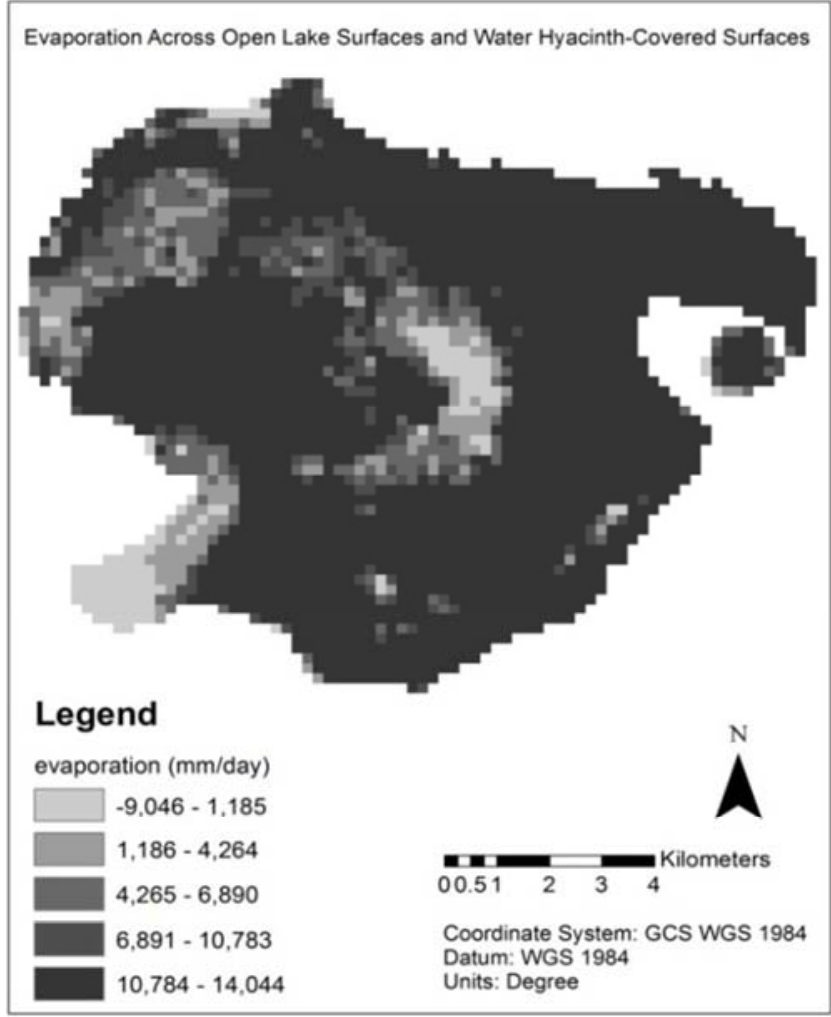

Figure 7. Evaporation/evapotranspiration rates map.

\section{Discussion}

The underlying goal of the study was to understand whether water hyacinth spread over the lake plays a significant role in the water level changes or not, especially the rising water level in the lake. As a result, it was designed to achieve the following objectives: determine water level changes in Lake Naivasha; establish the spatial-temporal spread of water hyacinth on Lake Naivasha and its relationship with the lake water level; explore possible causes of water level fluctuations in Lake Naivasha; and finally, analyse the effect of the growth of water hyacinth on water loss through surface heating that occurs on Lake Naivasha.

Water levels data obtained from the Water Resources Management Authority showed persistent water level fluctuations throughout the period that was covered (20002016). It also showed that the water level in the lake reached its lowest in February-March 2009. January-March is normally a dry period for the area around Lake Naivasha and Kenya as a country. From January 2010, the water level rose until May 2013 when it reached its highest level for the period. It has since maintained relatively high level. The observation was by the lake water surface area derived from Landsat images. The data also provided evidence of persistent surface area fluctuations, with the least water surface area observed in February 2009 and the largest surface area observed in February 2014.

There was evidence of increased human activities around the lake, which may partly explain the water level decline between 2000 and 2009. There was little change in human activities between 2000 and 2005. However, between 2005 and 2010, human activities around the lake increased significantly. The study did not find any evidence between mean monthly temperature or total monthly rainfall and water level in the lake or the surface area of the lake covered by water; however, there was almost significant relationship between rainfall received over Nyandarua slopes and the surface area of the lake covered by water as well as the lake's water level. Statistically significant, positive relationship between water hyacinth cover and water level in the lake or surface area of the lake covered by water was noted in the data analysis. Further data analysis showed that areas of the lake covered by water hyacinth lost less water to the atmosphere due to evaporation/evapotranspiration than open water surfaces of the lake. This suggests that water hyacinth on the lake reduces water outflow through evaporation, thereby contributing to the persistent high water level in the lake. This is consistent with [9] hypothesis that vegetation over the lake reduces evaporation. In other words, water hyacinth has a moderating effect on evaporation from the lake, which [1] found to be the highest cause of water outflow from the lake. As such, the large water hyacinth cover over the lake between 2010 and 2016 could explain the persistently high water levels. The evidence contradicts [41] earlier hypothesis that a major contributor to the declining water volume in Lake Victoria is the water hyacinth in the lake. We can therefore conclude that water hyacinth in Lake Naivasha is partly responsible for the high water level that affects human activities around the lake.

Recent studies $[2,18]$ have attributed the decline in the lake's water level to the floriculture and horticulture farms around the lake, which contribute excessive water extraction from the lake and the surrounding aquifers. It was estimated 
that the total virtual water exported through the cut flower industry from the lake basin to be $1.6 \times 10^{7} \mathrm{~m}^{3}$ per year during the period 1996-2005 [42]. The observed water level increase is consistent with the high rainfall received in the basin in the period 2010-2011. The water level in the lake has remained relatively higher even though the amount of annual rainfall received within the basin has since declined to pre2010 levels. Likewise, annual temperatures over the lake have remained relatively constant at $16-17^{\circ} \mathrm{C}$ since 2000 . It is expected that other factors held constant, low temperatures would reduce the rate of water loss from the lake through surface heating [39], which could explain the persistently high water levels despite decline in rainfall received in the region.

Regression analysis results did not show any relationship between rainfall and water level or between temperature and water level. The study did not find any evidence between monthly rainfall over the lake and water level in the lake or the surface area of the lake covered by water, which is consistent with the findings of [8]. Even the combined effect of rainfall and temperature had no relationship with the lake's water level. It is therefore difficult to explain the persistent high water level in the lake. These findings are consistent with the results of [7] which also failed to find any correlation between changes in precipitation and decline in the lake volume over a much longer period (1960-2010) than the period covered in the present study (2000-2016). There was partial evidence to support the findings of [40] that the water level in the lake is largely determined by the amount of rainfall received in the Kenyan highlands. Similar observation was also made in [1]. The analysis showed almost significant relationship between rainfall received over Nyandarua slopes and the surface area of the lake covered by water as well as the lake's water level.

According to [43], a reduction of the rainfall received for the 3-month (March-May) wet season would significantly reduce water recharge leading to decline in the water level. This view is supported by Bergner et al.'s model which showed that higher lake levels and larger lake surfaces are always the result of increased precipitation and/or decreased evapotranspiration and seepage [9]. The authors noted that this remains true as long as the lake basin's geometry is not affected by tectonic movement, suggesting that tectonic movement could be responsible for the current high lake level. However, there was no evaporation data to confirm the findings [9] which showed that increased rainfall and decreased evaporation, especially in the dry season $[1,43]$, is responsible for high lake water level.

Just like [9], [44] also provides another dimension to the current high water level in the lake. The author suggests that the rise in water level is occasioned by sediment loading from surface runoffs and rivers that flow into the lake. The results of the study showed that sediment load deposited at the bottom of the lake has been growing. The sediments are evenly spread over the depositional area of the lake bottom thereby increasing the average thickness of the bottom. This process is aided by the deforestation that occurs around the lake and upstream. This means that persistent heavy rains especially after prolonged drought would increase soil sediments deposition at the bottom of the lake and in turn increase the level. However, even this would require quite a long period to achieve meaningful rise in water level. For example, it was estimated that sediment deposition at the bottom of the lake in the period 1957-2001 to be $1.9 \times 10^{7} \mathrm{~m}^{3}$ of sediment which increased the thickness of the lake bottom by $0.21 \mathrm{~m}$ on average [44].

\section{Conclusion}

The study sought to investigate the role of water hyacinth on the lake's water level taking into consideration the role of rainfall patterns, temperature, and human activities around the lake. The results of the study were expected to bridge knowledge gap on the effects of the water hyacinth on Lake Naivasha. The observed water level increase is consistent with the high rainfall received in the basin in the period 2010-2011. The water level in the lake has remained relatively higher even though the amount of annual rainfall received within the basin has since declined to pre-2010 levels. The study has shown that rainfall received around Nyandarua slopes is partly responsible for the changes in Lake Naivasha while water hyacinth over the lake plays a moderating role on the evaporation that occurs over the lake. On the other hand, human activities around the lake, particularly agriculture, are growing leading to increasing water abstraction from the lake. However, the study did not find any evidence between monthly rainfall over the lake or mean monthly temperature over the lake and water level in the lake or the surface area of the lake covered by water.

The study has shown that GIS and remote sensing techniques enhance application of the SEBAL model in calculating evaporation/evapotanspiration. The study outlines a clear procedure for calculating evaporation / evapotranspiration rate on the lake based on the SEBAL model, using Landsat data and ground observed data. The major limitation of this study lies in the source of the data that was used. The lake water levels data had numerous missing data points while some data points contradicted the prevailing water level pattern. Therefore, the observed results on lake water levels may not be accurate. Besides, the study used Landsat satellite images which are low resolutions. Low resolution images tend to suffer co-registration that causes discrepancies and errors during manual editing for filtering water hyacinth cover. The problem was further compounded by the strips in Landsat 7 (ETM + ) SLC-off images. The algorithm used to fill in the gaps employ interpolation techniques which may not yield accurate results.

The study has shown that remote sensing technology can be used to monitor water hyacinth growth over the lake, accurately show the regions infested by the weed and extent of lake area cover, and inform weed control efforts. This means that by controlling the weed, we can protect the human activities around the lake. Using remote sensing techniques, it is easy to direct resources for more effective 
water hyacinth growth control. Though the role of vegetation around the lake on evaporation over the lake was not the focus of this study, the findings of the present study suggests that vegetation around the lake has a cooling effect that can reduce evaporation rates. Besides, the study has shown that vegetation affects the zero displacement of lake plane, roughness length, and wind speed. This information can be used to inform water resources management policy.

The water hyacinth cover though seems to moderate evaporation from the lake thereby reducing the rate of water level decline; there are certainly other factors that determine the lake's water level. The amount of rainfall in the catchment region for the rivers flowing into the lake seems to be an important determinant though this study did not find an absolute significant relationship between rainfall in this region and water level in the lake. Other authors have suggested plate tectonic movements and sediment deposition as other important factors that contribute to rise in the lake's water level. However, these factors have not been explored lately. Therefore, future studies should investigate the role of these two factors together with the amount of rainfall in the river catchment regions in the high lake water level. Future studies on the relationship between water hyacinth growth and the lake's water level changes should also look into the role of the mass of part of the weed submerged in the water on the rise of the water level. Future studies on the relationship between water hyacinth growth and the lake's water level should also look into the role of the mass of part of the weed submerged in the water on the rising water level. Such studies should also compare evaporation over the lake before and after the growth of water hyacinth over the lake using ground observed data.

\section{Appendix}

Table A1. Area of Lake Naivasha covered by water.

\begin{tabular}{|c|c|c|c|c|c|}
\hline Date & Area $\left(\mathrm{km}^{2}\right)$ & Date & Area $\left(\mathrm{km}^{2}\right)$ & Date & Area $\left(\mathrm{km}^{2}\right)$ \\
\hline Jan-2000 & 132.1371 & March-2005 & 126.9486 & Sept-2011 & 138.2292 \\
\hline May-2000 & 129.1977 & Jan-2006 & 123.489 & Jan-2012 & 136.35 \\
\hline Feb-2001 & 126.5994 & April-2006 & 120.8881 & Feb-2013 & 147.4021 \\
\hline April-2001 & 125.3403 & April-2007 & 127.0242 & Jan-2014 & 140.6032 \\
\hline Feb-2002 & 126.8028 & Dec-2007 & 127.6794 & Feb-2014 & 149.4394 \\
\hline July-2002 & 128.2005 & March-2008 & 129.6468 & June-2014 & 141.354 \\
\hline Feb-2003 & 126.0126 & Oct-2008 & 123.5295 & Dec-2014 & 141.4071 \\
\hline May-2004 & 132.7455 & June-2009 & 119.0178 & Feb-2015 & 142.3476 \\
\hline Nov-2004 & 128.4138 & Jan-2010 & 122.1003 & Feb-2016 & 142.515 \\
\hline Feb-2005 & 127.7271 & Feb-2011 & 129.8439 & Sept 2016 & 137.6307 \\
\hline
\end{tabular}

Table A2. Water hyacinth cover on Lake Naivasha.

\begin{tabular}{|c|c|c|c|c|c|}
\hline Date & Area $\left(\mathrm{km}^{2}\right)$ & Date & Area $\left(\mathrm{km}^{2}\right)$ & Date & Area $\left(\mathrm{km}^{2}\right)$ \\
\hline Jan-2000 & 1.2258 & March-2005 & 0.7173 & Sept-2011 & 19.2105 \\
\hline May-2000 & 0.963 & Jan-2006 & 2.583 & Jan-2012 & 31.1877 \\
\hline Feb-2001 & 1.1052 & April-2006 & 2.2347 & Feb-2013 & 18.3465 \\
\hline April-2001 & 1.683 & April-2007 & 9.0072 & Jan-2014 & 15.6402 \\
\hline Feb-2002 & 2.7207 & Dec-2007 & 6.4764 & Feb-2014 & 17.8587 \\
\hline July-2002 & 1.2429 & March-2008 & 6.7743 & June-2014 & 7.5942 \\
\hline Feb-2003 & 2.142 & Oct-2008 & 6.0804 & Dec-2014 & 10.8882 \\
\hline May-2004 & 1.6389 & June-2009 & 4.8168 & Feb-2015 & 9.063 \\
\hline Nov-2004 & 1.2492 & Jan-2010 & 17.5392 & Feb-2016 & 12.9672 \\
\hline Feb-2005 & 2.1897 & Feb-2011 & 12.6567 & Sept-2016 & 2.4345 \\
\hline
\end{tabular}

Table A3. Evaporation/evapotranspiration rates.

\begin{tabular}{lll}
\hline Date & Open water surfaces $(\mathbf{m m} /$ day) & Water hyacinth covered surfaces $(\mathbf{m m} /$ day) \\
\hline $11 / 07 / 2002$ & 30700 & 27877 \\
$04 / 02 / 2003$ & 10590 & 5200 \\
$21 / 11 / 2004$ & 6216 & 2447 \\
$13 / 03 / 2005$ & 23141 & 16477 \\
$27 / 01 / 2006$ & 22011 & 12418 \\
$01.04 / 2006$ & 23318 & 15611 \\
$08 / 03 / 2009$ & 12995 & 5841 \\
$12 / 06 / 2009$ & 10472 & 1943 \\
$22 / 01 / 2010$ & 18394 & 4006 \\
$16 / 01 / 2012$ & 13333 & 3380 \\
$16 / 02 / 2016$ & 5097 & 705 \\
$27 / 09 / 2016$ & 23525 & 18446 \\
\hline
\end{tabular}




\section{References}

[1] Reta, Gebrehiwwet Legese. "Groundwater and lake water balance of Lake Naivasha using 3-D transient groundwater model." Master Thesis, University of Twente, 2011.

[2] Ruhakana Alabert. Estimation of the change of Lake Naivasha using earth observation, GIS, and hydrological model, 2015. $\begin{array}{llll}\text { Accessed } & 22 & \text { February }\end{array}$ https://www.geotechrwanda2015.com/wpcontent/uploads/2015/12/176_Albert-Ruhakana.pdf.

[3] Kyambia, Marshal M. and Mutua, Benedict M., "Detection of trends in extreme streamflow due to climate variability in the Lake Naivasha basin, Kenya," International Journal of River Basin Management 13, no. 1 (2014): 97-103.

[4] Lal, Perakum Muthuwatta. "Long-term rainfall runoff: Lake level modelling of the Lake Naivasha basin, Kenya." Master Thesis, International Institute for Geo-Information Science and Earth Observation, 2004.

[5] Farah, Hussein Omar. "Estimation of regional evaporation under different weather conditions from satellite and meteorological data: A case study in the Naivasha basin, Kenya." PhD Thesis, Wageningen University, 2001.

[6] Arlan, Perkasa Lukman. Regional impact of climate change and variability on water resources Lake Naivasha basin, Kenya. Queensland: ITC, 2003.

[7] Odongo Vincent O., Christian van der Tol, Pieter R. van Oel, Frank M. Meins, Robert Becht, Japheth Onyando, and Zhongbo Su. "Characterisation of hydroclimatological trends and variability in the Lake Naivasha basin, Kenya," Hydrological Processes, 29, Issue 15 (January 2015): 32763293.

[8] Trottman, Damali K. "Modelling groundwater storage change in response to fluctuating levels of Lake Naivasha, Kenya." Master Thesis, International Institute for Aerospace Survey and Earth Sciences (ITC), 1998.

[9] Bergner, Adreas G. N., Martin H. Trauth, and Bodo Bookhagen. "Paleoprecipitation estimates for the Lake Naivasha basin (Kenya) during the last 175 k. y. using a lakebalance model," Global and Planetary Change 36 (March 2003): 117-136.

[10] Becht, Robert, Eric O. Odada, and Sarah Higgins. "Lake Naivasha: Experience and lessons learned brief," In Lake basin management initiative: Experience and lessons learned briefs, 277-298. Kusatsu: International Lake Environment Committe Foundation (ILEC), 2005.

[11] Dergachev V. A., O. M. Raspopov, F. Damblon, H. Jungner, and G. I. Zaitseva. Natural climate variability during the Holocene. Radiocarbon 49, no. 2 (2007): 837-854.

[12] World Lake Database, n. d. Lake Naivasha, International Lake Environment Committee. Available at http://wldb.ilec.or.jp/Details/Data/10204/Lake\%20Naivasha. Accessed 27 January 2017.

[13] Mironga, John M., J. M. Mathooko, and Simon M. Onywere. "The effect of water hyacinth (eichhornia crassipes) infestation on phytoplankton productivity in Lake Naivasha and the status of control," Journal of Environmental Science and Engineering 5 (2011): 1252-1260.

[14] University of Leicester. "Saving Kenya's Lake Naivasha: Efforts to improve sustainability." ScienceDaily. Last Modified March 2011. Accessed 21 January 2017. www.sciencedaily.com/releases/2011/05/110511075034.htm.

[15] Makhanu, K. S."Impact of water hyacinth on Lake Victoria." In Water and Sanitation for All: Partnerships and Innovations, 165-166. Paper presented at the Proceedings of the $23^{\text {rd }}$ WEDC Conference, Durban, South Africa, 1997.

[16] Chamier, Jessica, Klaudia Schachtschneider, David C. le Maitre, Pete J. Ashton, and Brian van Wilgen. "Impacts of invasive alien plants on water quality, with particular emphasis on South Africa," Water SA 38, no. 2 (April 2012): 345-356.

[17] Gorgens A., and B. W. van Wilgen. "Invasive alien plants and water resources: An assessment of current understanding, predictive ability and research challenges," South African Journal of Science 100, Issue 1-2 (January/February 2004): 27-34.

[18] Awange, Joseph L., Ehsan Forootan, Jurgen Kusche, John B. K. Kiema, P. A. Omondi Bernhard Heck, Kevin Fleming, S. O. Ohanya, and Rodrigo M. Goncalves. "Understanding the decline of water storage across the Ramser-Lake Naivasha using satellite-based methods," Advances in Water Resources 60 (July 2013): 7-23.

[19] Kumar, G. Dinesh, B. M. Purushothaman, M. S. Vinaya, M. S., and S. Suresh Babu. "Estimation of evapotranspiration using MODIS sensor data in Udupi District of Karnataka, India," International Journal of Advanced Remote Sensing and GIS, 3, Issue 1 (2014): 532-543.

[20] Mutiga, Jeniffer K., Zhongbo Su, and Tsehaie Woldai. "Using satellite remote sensing to assess evapotranspiration: Case study of the upper Ewaso Ng'iro north basin, Kenya," International Journal of Applied Earth Observation and Geoinformation 125 (February 2010): S100-S108.

[21] Peng, J., Y. Liu, X. Zhao, and A. Loew. "Estimation of evapotranspiration from MODIS TOA radiances in the Poyang lake basin, China," Hydrology and Earth System Sciences 17 (2013): 1431-1444.

[22] Sun, Zhigang., Q-X Wang, Bunkei Matsushita, Takehiko Fukushima, Zhu Ouyang, and Masataka Watanabe "Development of a simple remote sensing evapotranspiration model (Sim-ReSET): Algorithm and model test," Journal of Hydrology 376, Issue 3-4 (October 2009): 476-485.

[23] Lu, Shanlong, Ninglei Ouyang, Bingfang Wu, Yongping Wei, and Zelalem Tesemma. "Lake water volume calculation with time series remote sensing images," International Journal of Remote Sensing, 34 no. 22 (September 2013): 7962-7973.

[24] Widyasamratri, Hasti, Kazuyoshi Souma, Tadashi Suetsugi, Hiroshi Ishidaira, Yutaka Ichikawa, Hiroshi Kobayashi, and Ichiko Inagaki. "Air temperature estimation from satellite remote sensing to detect the effect of urbanization in Jakarta, Indonesia," Journal of Emerging Trends in Engineering and Applied Sciences (JETEAS) 4, no. 6 (2013), 800-805.

[25] Qin, Zhihao, Arnon Karnieli, and Pedro Berliner, "A monoalgorithm for retrieving land surface temperature from Landsat TM data and its application to the Israel-Egypt border region," International Journal of Remote Sensing 22 no. 18 (November 2001): 583-594. 
[26] Smith, R. B. "The heat budget of the earth's surface deduced from space." Yale. edu, 2010. Accessed 15 June 2017. http://yceo.yale.edu/sites/default/files/files/Surface_Heat_Bud get_From_Space.pdf.

[27] Sun, Zhigang, Mekonnen Gebremichael, Qinxue Wang, Junming Wang, Ted W. Sammis T. W., and Alecia Nickless. "Evaluation of clear-sky incoming radiation estimating equations typically used in remote sensing evapotranspiration algorithms," Remote Sensing 5 (September 2013): 4735-4752.

[28] Murray, F. W. "On the computation of saturation vapour pressure," Journal of Applied Meteorology 6 (February 1967): 203-204.

[29] Vaisala. Humidity conversion formulas: Calculation formulas for humidity. Helsinki: Vaisala Oyj, 2013.

[30] Martin, Marlo, and Paul Berdahl. "Characteristics of infrared sky radiation in the United States," Solar Energy 33, no. 3-4 (1984): 321-336.

[31] Jackson, Ray D., William P. Kustas, and Bhaskar J. Choudhury. "A reexamination of the crop water-stress index," Irrigation Science 9, no. 4 (October 1988): 309-317.

[32] Linacre, E., and B. Geerts. "Roughness length." Das UWYO.edu, 1999. Accessed 16 May 2017. http://wwwdas.uwyo.edu/ geerts/cwx/notes/chap14/roughness.html.

[33] Brutsaert, Wilfried. Evaporation into the atmosphere. Dordrecht: Springer, 1982.

[34] Southeast Exotic Pest Control Council. "Southeast Exotic Pest Plant Council Invasive Plant Manual." SE-EPPC. org.

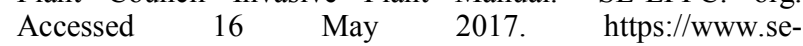
eppc.org/manual/EICR.html.

[35] Blumel, Klaus. "A simple formula for estimation of the roughness length for heat transfer over partly vegetated surfaces," Journal of Applied Meteorology 38, no. 6 (June 1999): 814-829.

[36] Singh, Ramesh K., and Gabriel B. Senay. "Comparison of four different energy balance models for estimating evapotranspiration in the Midwestern United States," Water 8, no. 1 (2016): 1-19.

[37] Mkhwanazi, Mcebisi, Jose L. Chavez, Allan A. Andales, and Kendal DeJonge. "SEBAL-A: A remote sensing ET algorithm that accounts for advection with limited data. Part I: Development and validation." Remote Sensing 7, no. 11 (November 2015): 15046-15067.

[38] Zahira, Souidi, Hamimed Abderrahmane, Khalladi Mederbal, and Donze Frederic. "Mapping latent heat flux in the western forest covered regions of Algeria using remote sensing data and a spatialized model." Remote Sensing 1, no. 4 (2009): 795-817.

[39] Ahluwalia, V. K., and Sudha Raghav. Comprehensive experimental chemistry. New Delhi: New Age International, 1997.

[40] Vincent, Christopher E., T. C. Davies, and A. K. C. Beresford. "Recent changes in the level of lake Naivasha, Kenya, as an indicator of equatorial Westerlies over Eastern Africa," Climate Change 2, Issue 2 (1979): 175-189.

[41] Kateregga, Eseza, and Thomas Sterner. "Lake Victoria fish stocks and the effects of water hyacinths on the catchability of fish. Environment for Development," The Journal of Environment \& Development 18, Issue 1 (2009): 62-78.

[42] Mekonnen, M. M., A. Y. Hoekstra, and R. Becht. "Mitigating the water footprint of export cut flowers from the Lake Naivasha Basin, Kenya," Water Resource Management 26 (October 2012): 3725-3742.

[43] Kull, Daniel. "Connections between recent water level drops in Lake Victoria, dam operations and drought," International Rivers Org., 2006. Accessed 19 January 2017. http://www.internationalrivers.org/files/attachedfiles/full_report_pdf.pdf.

[44] Rupasingha, R. A. P. "Use of GIS and RS for assessing lake sedimentation processes: Case study for Naivasha lake, Kenya." Master Thesis, International Institute for GeoInformation Science and Earth Observation Enschede, 2002. 